effluents. Typical analyses of waters used for locomotive boiler-feed are also included.

In conclusion, the book is a useful compilation which should prove of value not only to the industrial chemist but also to all those who have to examine waters as to their suitability for the many purposes for which they find a use. As the author says, he has only attempted to include a fraction of the known methods of analysis, and for other methods it would be necessary to refer to the larger text-books; but as already stated, he has provided an excellent guide to the wide subject of chemical analysis of waters.

H. T. Calvert.

\section{NUTRITION AND HEALTH}

Nutrition and National Health

Being the Cantor Lectures delivered before the Royal Society of Arts, 1936. By Major-General Sir Robert McCarrison. Pp. $75+3$ plates. (London: Faber and Faber, Ltd., 1944.) 6s. net.

THIS attractively written book is a re-publication $I$ of the three Cantor Lectures delivered to the Royal Society of Arts in 1936. The author was formerly director of research in nutrition in India.

The first lecture is devoted to the physiology of nutrition; the second to the relation of oxygen, water, proteins, mineral salts and vitamins to health and illness; the third to the effects of nutrition on national health. The whole constitutes a useful introduction to the study of a subject much in the public mind at present, illustrated throughout by references to the author's work in India and to results obtained in Great Britain.

If criticism is to be made, it might suggest that the opportunity of reprinting could have been taken to include some account of the creation and work of the Nutrition Society, that more recent researches might have been included and that more space might have been given to nutrition of those animals on which we depend for our food supplies and to the effects of the national food policy during this War. The education of the publie, the medieal student, the medical practitioner, the school teacher and others for which Sir Robert appeals has surely been going on vigorously in recent years, and the public is already very conscious of food values. It has learnied, too, the pleasure and advantage of growing its own greenstuffs and of producing its own eggs, thanks to the national policy of aiding both these enterprises. It may still be true that greenstuffs have already lost much of their food value before they reach the poor, but this can only be true of large cities and only of parts of these; for everywhere within and outside them allotments have been growing vast quantities of vegetables for some years, and it is a little late in the day to advocate, as Sir Robert does, the extension of these and of facilities for keeping poultry. There are parts of the country, indeed, in which people cannot eat all the greenstuffs that they grow.

The book is a beautiful example of what can be done within the limits of the authorized war-time standards of economy. Some readers will wonder why, if books like this can be produced within such limits, more of them do not appear. For the same reason some may even wonder whether any other standards will be really needed after the War.

G. LAPAGE.

\section{PHILOSOPHY OF ORGANISM}

A Contribution to the Theory of the Living Organism

By Prof. W. E. Agar. Pp. 207. (Melbourne: Melbourne University Press; London: Oxford University Press, 1943.) 12s. 6d.

THE keynote of Prof. Agar's book, in which he has drawn freely upon the materials both of philosophy and biology, is frankness, directness and lucidity. At least some preliminary contact with the biological philosophy of Whitehead is demanded of the reader. The main thesis is that all living organisms are subjects, that all, possibly including even the simplest, are organizations of subjects, and that the characteristic activity of a subject is the act of perception. In this perception he sees the establishment by the subject of its causal relation with the external world. Even in inanimate objects, process is conceived as one of experience or feeling. In developing this thesis, in which Whitehead's philosophy of organism is freely invoked, many aspects of the organism, especially those of which we have knowledge from experimental investigation, are discussed with refreshing lucidity.

In treating the component parts of living organisms, even at the level of cells or cell aggregates, as feeling, perceiving subjects, the author realizes that he is introducing an interpretation which is likely to be opposed or denied by many biologists. Thus, for example, he writes: "As perception always carries with it the anticipation of further relevant experience, and the meaning of the present experience includes action, or potential action, appropriate to the anticipation, the notion of final causation is involved ... the anticipatory aspect of causation compels us to recognize the reality of final causation in all perceiving organisms". Thus, in this connexion the teleological nature of causation is recognized. The author is well aware that in adopting this point of view he is treading dangerous ground - that in which science and philosophy stand in danger of becoming confused-but he is prepared to maintain his position and to justify his views. The thesis which, in some respects, is the antithesis of a mechanistic theory, thus rejects the view that "biology is only a science so long as it is only biochemistry and biophysics".

Consideration is given to such topics as purposive action and its interpretation, the unity of the organism considered in the light of experimental studies, biological fields, Gestalt psychology, animal behaviour in terms of perception, and aspects of embryonic development and its interpretation as behaviour. In a final chapter the conclusions reached are considered in relation to the Darwinian and Lamarckian views of the process of evolution, a verdict in favour of the former being given. If his thesis is correct, says Prof. Agar, biologists must accept perception as one of their ultimate data; but he admits that even in imagination it is not easy to trace "the detailed course of the evolution of the higher out of the lower types of perception".

No adequate short review of this book is possible, for the book is itself commendably short, and while full of meat, yet does not give the impression of being crowded. If biologists admit that they should give heed to the trend of thought in Whitehead's philosophy of organism, as sooner or later it seems they must, then they would do well to read this book. 